\title{
Proximate Composition of Some Selected Browse Plants in Gombi Local Government Area, Adamawa State, Nigeria
}

\author{
Mojaba, D.I*, Khobe, D $^{* *}$, Nelson, $\mathbf{E}^{*}$ \\ * Department of Animal Production, Adamawa State University, Nigeria \\ ** Departement of Crop Science, Adamawa State University, Nigeria
}

\begin{tabular}{l}
\hline \hline Article Info \\
\hline Article history: \\
Received Mar 18, 2016 \\
Revised May 14, 2016 \\
Accepted May 27, 2016
\end{tabular}

\section{Keyword:}

Browse Plants

Proximate Composition

Ruminant Animal Production

\begin{abstract}
Twelve (12) indigenous browse plants harvested from four districts of Gombi Local Government, Adamawa State were evaluated for their proximate composition. The samples were randomly collected in the study and identified at the Forestry Department, Ministry of Agriculture, Adamawa State. The proximate composition of the collected samples was carried out at the Animal production Nutrition Laboratory of Adamawa University, Mubi. Parameters measured include dry matter (DM), crude fibre (CF), crude protein (CP), Ash (minerals). Nitrogen free extract (NFE) and ether extract (EE). Results obtained showed that DM ranged from 55.5\%-80\%, CF (23$68 \%)$, CP (7.88-19.25\%), NFE (22.25-69.97\%), EE (3.0-6.0\%) and Ash (6.0$12.00 \%)$. The data obtained were used to determine the suitability of the browse plants species for ruminant animal production. Results revealed that nutrient contents in plant samples vary in composition.
\end{abstract}

Copyright $@ 2016$ Institute of Advanced Engineering and Science. All rights reserved.

\section{Corresponding Author:}

Khobe, D.I,

Department of Crop Science,

Adamawa State University,

P.M.B. 25, Mubi, Nigeria

Email: khobe_dishi@yahoo.com

\section{INTRODUCTION}

Trees and shrubs have provided valuable forage to man's domesticated animals. When pasture deteriorates, the protein content falls to levels where nitrogen supply to the ruminant microbes limits their activity to improve the protein status of the animals and probably increase intake. Browse plants can be an important supplement for animals grazing on low quality grass pasture (Menninman et al., 1986). Brewbaker (1986) defined browse as the leaves, shoots and sprouts including tender twigs and stems of woody plants, which are cropped to a varying extent by domestic and wild animals. Browse plants form important components of diets of goats, sheep, camels, cattle and buffalos. Ruminants depend greatly on browse to meet their feeding requirements (Devendra and Burns, 1983). Fodder trees and shrubs have played important roles in feeding livestock. They constitute a vital component in livestock productivity in the arid and semiarid zones of the world where about $52 \%, 57 \%$ and $63 \%$ of cattle, sheep and goats respectively are highly produced (Ahn et al., 1989). Trees and shrubs are increasingly recognised as important components of animal feeds, especially as suppliers of protein. They are readily accepted by livestock and presumably because of their deep-root systems, they continue to produce well into the dry season (Paterson et al., 1998). Traditional herdsmen have noted that the use of browse plants is necessary during dry season. Pastoralists cut down ranches of browse plants species such as Ficus sycomorus, Balanites aegyptiaca and Adansonia digitata to balance the dietary ratio in livestock during dry season (Dietz, 1979).

The major livestock production areas of northern Nigeria are characterised by long dry season and consequently, forage is available for a short period only, after which it declines in both quantity and quality (Olayiwole, 1986). In this part of the country, ruminant animals suffer greatly due to malnutrition. The 
nutrient available in the grass during the dry season cannot meet their maintenance level, which therefore, makes most animals depend on other non-conventional sources of supplementary diet (Le Houerou, 1990). More than $50 \%$ of the total dry matter (DM) intake of sheep and goats were found to be accounted for by browse plants (Adegbola, 1995).

Nzamane (1984) reported that the leaves of browse plants are rich in protein and minerals. Similarly, acacia seeds contain $18.6 \%$ crude protein, $4 \%$ ether extract, $10 \%$ crude fibre, $16.2 \%$ nitrogen free extract, $5.2 \%$ ash and $0.29 \%$ phosphorus. Variations exists in the chemical composition of browse plants, which may be caused by species difference, season of the year, location and part of the plant leaves, fruits, twigs, flowers or bark (Nzamane, 1984). This study determined the chemical composition, nutritive value, anti-nutritional values of twelve (12) selected browse plants and their suitability for ruminant animal production in Gombi Local Government Area of Adamawa State.

\section{MATERIALS AND METHODS}

The survey for collection of browse plants was done in Gombi Local Government Area $\left(10^{\circ} 05 \mathrm{~N}^{\prime}\right.$ and $22^{\circ} 05^{\prime} \mathrm{E}$ and $28,000 \mathrm{~km}^{2}$ ). The maximum temperature was $35.7^{\circ} \mathrm{C}$ in April, and the minimum was $25^{\circ} \mathrm{C}$ in January for season in which the study was done. Fresh leaves from the apical portions of the branches of twelve (12) selected browse plants (Table 1) were randomly collected at various locations in the study area. Three (3) samples were collected from each of the four (4) Districts of the Local Government. Collection was carried out within one month. Five hundred grams $(500 \mathrm{~g})$ of fresh leaves were weighed and labelled by their botanical, common names and local names for ease of identification (Table 1). The samples were identified at the Forestry Department, Adamawa State Ministry of Agriculture, and Yola.

Table 1. List Of Browse Plants Used for the Study.

\begin{tabular}{ccc}
\hline Botanical Name & Common Name & Local Name (Hausa) \\
\hline Khaya senegalensis & Mahogany & Madachi \\
Vittelaria paradoxum & Shea butter & Kadanya \\
Anogeissus leiocarpus & Chew stick & Marke \\
Daniella oliveri & Copaiba balsam & Maje \\
Ficus valficus & Ficus species & Ganji \\
Vitex doniana & Black plum & Dinya \\
Terminalia glaucescens & Ficus species & Baushe \\
Ficus sycomorus & Ficus species & Baure \\
Berlinia doka & Ficus species & Farar doka \\
Diospyros mespiliformes & Ebony & Kanya \\
Adansonia digitata & Baobab & Kuka \\
Acacia tortilis & Mimoseni & Farin kaya \\
\hline
\end{tabular}

Source: Field data (2010)

\subsection{Pre-Treatment of Samples}

The samples collected were ground to powder using laboratory blender and sieved using $1 \mathrm{~mm}$ mesh sieve. Each ground sample was put in a labelled polythene bag and stored in desiccators to avoid moisture absorption, ready for laboratory analysis.

\subsection{Proximate Analysis}

Proximate composition of the collected samples was carried out at the Animal Science Laboratory of Adamawa State University, Mubi. Fresh foliage of the selected browse plants were sun-dried for 5 days, cut into pieces $(2 \mathrm{~cm}-5 \mathrm{~cm})$ with a knife, oven-dried at $65 \%$ for 24 hours and ground through $1 \mathrm{~mm}$ screen for subsequent analysis. Proximate composition was determined for percentage dry matter (DM), crude protein $(\mathrm{CP})$, crude fibre $(\mathrm{CF})$, ether extract $(\mathrm{EE})$ and ash while nitrogen free extract (NFE) was calculated by subtraction using the formula:

$$
\text { Percentage NFE }=\quad 100-(\% \mathrm{CP}+\% \mathrm{CF}+\% \mathrm{EE}+\% \mathrm{ash})
$$

\subsection{Dry Matter (DM) Determination}

For dry matter determination fresh sample was weighed and dried to constant weight in an oven. The percentage dry matter was then determined by the formula; 
Weight of crucible + sample before oven drying - weight of crucible x 100

Weight of crucible - weight of sample

Percentage DM $=\quad$ Final Weight $\times 100$

Initial weight

\subsection{Determination of Crude Protein}

Crude protein (CP) was determined using micro Kjeldahl method as described by Skoog and Donald (1974). These include digestion, distillation and titration. The digestion was done by weighing $2 \mathrm{~g}$ of sample into $500 \mathrm{ml} \mathrm{Kjeldahl} \mathrm{digestion} \mathrm{flask} \mathrm{and} \mathrm{adding} 7 \mathrm{~g}$ potassium sulphate to the mixture. Thereafter $0.5 \mathrm{~g}$ of crystal copper sulphate (catalyst) and $15 \mathrm{ml}$ concentrated $\mathrm{H}_{2} \mathrm{SO}_{4}$ were also added. The flask was dampened in an inclined position in a woody cupboard that has in-built extractor because the fume generated by the process is highly toxic and choky. The mixture was then heated to boil until a clear light blue or green solution was obtained. The solution was allowed to cool, and transferred into a $100 \mathrm{ml}$ standard or volumetric flask. This was then diluted with distilled water and filled up to make the solution ready for distillation. The distillation procedure consisted of putting $25 \mathrm{ml}$ of the digest into the micro Kjeldahl, and then adding $25 \mathrm{ml}$ of $40 \%$ sodium hydroxide. A blue colouration was formed which turned dark brown as distillation proceeded. The released ammonia was condensed and collected into a receiver containing $10 \mathrm{ml}$ of boric acid. The pinkish boric acid colour changed into a green colour because nitrogen in form of ammonia was absorbed by boric acid solution. The ammonia was then distilled till the volume of boric acid became 50ml. After distillation, the green coloured ammonium borate was then back titrated with $0.01 \mathrm{ml} \mathrm{HCl}$ acid until the end point of the pink colour was obtained. The distillate was then tested for three neutral litmus papers until the neutral test was obtained.

\section{DATA ANALYSES}

After all the analysis, the amount of nitrogen present in the sample was calculated. The calculation was performed as percentage nitrogen and percentage protein in the sample.

\subsection{Percentage Nitrogen $(\mathbf{P N})$}

$\mathrm{PN}=\underline{14.01 \times(\mathrm{ml} \text { titrate-blank })-(\mathrm{N} \text { of titrate })} \times 100$

$$
\text { Sample wt. (grams) x } 1000
$$

The conversion factor was obtained by dividing 100 by $16=6.25$

Therefore, percentage protein was determined using the relationship $6.25 \times \% \mathrm{~N}$.

\subsection{Crude Fibre Determination}

Crude fibre was determined according to AOAC (1994) in which $2 \mathrm{~g}$ of the sample was weighed in a $250 \mathrm{ml}$ conical flask and $100 \mathrm{ml}$ TCA reagent was added to the sample and digested by refluxing for 40 minutes. It was then filtered to obtain the residue. The residue was washed 6 times with distilled boiling water and finally with $10 \mathrm{mls}$ of acetone. The residue was transferred to an oven and dried at $105^{\circ} \mathrm{C}$ overnight. The residue was scraped into the crucible and weighed; ashing was done in a muffle furnace at $550^{\circ} \mathrm{C}$ for 2 hours. The ash sample was removed and cooled in desiccators after which the ash was weighed together with the crucible.

$$
\begin{aligned}
& \text { Weight of crucible + residue }=\quad \mathrm{W}_{2} \\
& \text { Weight of crucible }+ \text { ash }=\quad \mathrm{W}_{3} \\
& \text { Weight of sample }=\quad \mathrm{W}_{1} \\
& \text { Weight of crucible +residue - weight of crucible+ash } \times 100 \\
& \text { Initial sample weight }(2 \mathrm{~g}) \\
& \text { Percentage } C F=\frac{\mathrm{W}_{2}}{\mathrm{~W}_{1}}-\mathrm{W}_{3} \times 100
\end{aligned}
$$

\subsection{Determination of Total Ash}

The total content of mineral matter or total ash, i.e., non-combustible portion of the feed was determined. Two grams ( $2 \mathrm{~g}$ ) of sample was weighed in a silica crucible. The sample was ignited on a burner until smoke ceases. The crucible was placed in a muffle furnace and heated to $600^{\circ} \mathrm{C}$ for 2 hrs. At this 
temperature all organic matter were burnt leaving behind minerals. The crucible was removed from the furnace carefully and cooled in desiccators at room temperature and weighed again.

$$
\text { Percentage Ash }=\quad \underline{\mathrm{W}}_{\underline{2}}-\mathrm{W}_{0} \quad \begin{gathered}
\mathrm{X} \\
\mathrm{W}_{1}-\mathrm{W}_{0}
\end{gathered}
$$

Where $\mathrm{W}_{0}=$ weight of empty crucible,

$\mathrm{W}_{2}=$ crucible + sample,

$\mathrm{W}_{1}=$ crucible + sample after burning.

\subsection{Ether Extract Determination}

The crude fat (a combination of simple fat, fatty acid, esters, compound fat, neutral fat, sterols, waxes, vitamins $\mathrm{A}, \mathrm{D}_{2}, \mathrm{E}, \mathrm{K}$, carotene, chlorophyll, etc.) soluble in ether was estimated by extraction method. Two (2) grams of the sample was weighed on the dry filter paper/thimble and inserted into a Soxhlet's apparatus. $150 \mathrm{mls}$ of petroleum ether was poured into the flask. The soxhlet's apparatus was immediately joined to the flask containing the petroleum ether. The soxhlet was connected to a condenser clamped to a retort stand. The flask was then heated until the content started boiling. The fat was separated from the petroleum ether through distillation. After distillation, the flask containing the fat was dried, cooled in desiccators and weighed.

Percentage EE $=$ Wt. of thimble + sample before extraction - wt. of thimble + sample after extraction x 100

$2 \mathrm{~g}$ (initial wt. of sample)

\subsection{Nitrogen Free Extracts (NFE) Determination}

The NFE was calculated by using the formula:

Percentage NFE $=100-(\% \mathrm{CP}+\% \mathrm{CF}+\% \mathrm{EE}+\%$ Ash $)$.

\section{RESULTS AND DISCUSSION}

The results of proximate composition of the selected browse plants are presented in Table 2. The dry matter content of browse plants were on average higher ranging from $55.5 \%$ in Daniella oliveri to $80 \%$ in Ficus valficus. This agrees with the report of Agishi (1985) that the amount of dry matter in dry season browse plants is generally higher. The result also show that some of the browse plants were found to have high crude protein content; Daniela oliveri (19.25\%), Diopyros mespiliformis (17.50\%), Vitellaria paradoxum (16.63\%), Acacia tortilis (15.75\%) and Isoberlinia doka (15.56\%). Earlier Le Houerou (1990) stated that some tree leaves possess high crude protein content of $15.26 \%$ on the average. The result implies that more proteins may be made available to animals feeding on dry season browse plants. This is importance since animals in this region thrive mostly on browse plants during the long dry season when there are no pasture grasses.

The crude fibre obtained in this study ranged from $23-68 \%$ with the lowest value in Khaya senegalensis while the highest crude fibre was in Adansonia digitata. This may be due to differences in plant species and the stages of maturity. Young and tender leaves have low fibre content as compared to matured older leaves (ARC, 1985). The ash contents ranged from $6.0-12.0 \%$ with fiscus sycomorus having the highest, Khaya senegalensis and Vitex doniana 11.5\%, Anogeissus leiocarpus and Adansonia digitata (10.5\%). Considering the high values of ash obtained in this work, it shows that most of the browse plants can be of high feeding value to ruminants since the presence of high value of ash indicates the total minerals content of the feed (Kapu, 1975). Ether extract was lowest in Fiscus valficus (3.0\%) and highest in Adansonia digitata and Daniella Oliveri $(6.0 \%)$. On the average, the values are higher suggesting the presence of lipid in large quantity in one browse plant which may probably lead to the acceptability of the feed by ruminants because of improved palatability. Similarly, browse plants with high NFE are likely to contain high energy that may be useful for high consumption by ruminants ((NRC, 1981). NFE were found to be high in Vitellaria paradoxum, Ficus Sycomorus, Acacia tortilis, Khaya senegalensis and Terminalia glaucescens ranging from $22.25-69.97 \%$. 
Table 2. Proximate Composition of Browse Plants Evaluated In the Study

\begin{tabular}{|c|c|c|c|c|c|c|c|}
\hline $\mathrm{S} / \mathrm{N}$ & Sample & $\mathrm{DM}$ & $\mathrm{CP}$ & $\mathrm{CF}$ & $\mathrm{EE}$ & Ash & NFE \\
\hline 1. & Khaya senegalensis & 70 & 13.50 & 23 & 4.0 & 11.5 & 48 \\
\hline 2. & Vittelaria paradoxum & 72.5 & 16.63 & 24 & 5.0 & 6.0 & 69.97 \\
\hline 3. & Anogeissus leiocarpus & 56 & 7.88 & 58 & 3.5 & 10.5 & 23.12 \\
\hline 4. & Daniella oliveri & 55.5 & 19.25 & 37 & 6.0 & 8.0 & 29.75 \\
\hline 5. & Ficus valficus & 80 & 14.00 & 41 & 3.0 & 11.5 & 30.5 \\
\hline 6. & Vitex doniana & 60 & 12.25 & 54 & 4.0 & 7.5 & 22.25 \\
\hline 7. & Terminalia glauscescens & 70 & 11.00 & 32 & 5.5 & 7.5 & 44 \\
\hline 8. & Ficus sycomorus & 72.5 & 12.25 & 26 & 4.0 & 12.0 & 45.75 \\
\hline 9. & Isoberlinia doka & 75 & 15.56 & 37 & 3.5 & 7.0 & 36.94 \\
\hline 10. & Diospyros mespiliformes & 70 & 17.50 & 61 & 5.0 & 8.5 & 38 \\
\hline 11. & Adansonia digitata & 73 & 9.13 & 68 & 6.0 & 10.5 & 28.37 \\
\hline 12. & Acacia tortilis & 62.5 & 15.75 & 25 & 4.5 & 9.0 & 45.75 \\
\hline
\end{tabular}

DM (dry matter); CP (crude protein); CF (crude fibre); EE (ether extract); NFE (Nitrogen free extract)

\section{CONCLUSION}

In conclusion, the browse plants in Gombi Local Government Area of Adamawa State were found to have good levels of dietary nutrients, particularly proteins that are required for ruminant animal production especially during the dry season. The study revealed that among the browse plants Daniella Oliveri (19.25\%), Diopyros mespiliformis (17.50\%), Vittelaria paradoxum (16.63), Acacia tortilis (15.75\%) and Isoberlinia doka $(15.56 \%)$ have better nutritional profile especially protein while Khaya senegalensis, Anogeissus leiocarpus, ficus valficus, Vitex doniana, Terminalia glaucescens, ficus sycomorus, and Adansonia digitata are browse plants of low nutritional profile.

\section{RECOMMENDATIONS}

In order to improve animal production in the study area, it is recommended that techniques for managing and preserving browse forages with promising nutritional profile should be developed. Secondly, more browse plants should be screened in order to know their potentials for animal production. Further research should be directed to the determination of nutrients and anti-nutritional factors such as tannins, oxalates, nitrites, saponins and alkaloids. Finally, feeding trials using ruminant animals is recommended in order to fully ascertain the nutritional values of these browse plants.

\section{REFERENCES}

[1] Adegbola, T, A. Chemical composition and in vitro digestibility of some cultivated forages in dry season. Journal of Animal Production Research. 1995: 10 (1): 21-29.

[2] Agishi, E.C. Forage resources of Nigeria's rangeland. Proceedings of. 1985.

[3] Ahn, J.H., Robertson, B.M., Edotor, R., Gutter, R.C. and Ford, C.W. Quality assessment of tropical browse plants legumes, tannin content and protein degradation. Animal feed science and technology. 1989: 27: 147-156.

[4] AOAC. The official methods of analysis. Association of Official Analytical Chemists. $15^{\text {th }}$ Ed., Washington DC. 1994: 803-845.

[5] ARC (1985). Agricultural research council. The nutrient requirements of farm animals, Ruminants Tech. Rev. of summaries, ARC, London. 1985: 2.

[6] Brewbaker, J.L. Browse management and improvement. In Proceedings of workshop at CATITURRIAL Costa Rica, NFTA, Special publication. 1986: 91: 31-42.

[7] Devendra, C. and Burns, M. Goat Production in the tropics. Commonwealth agriculture bureaux. 1983: 90-115.

[8] Dietz, D. Definition and component of forage quality range and wildlife habitat evaluation. A resource symposium, miscellaneous publications: 1147 US, Department of Agriculture. 1979: 1-9.

[9] Kapu, A.M. (1975). The natural forest of northern Nigeria. Nigerian Journal of Animal Production. 1975: 2: 235246.

[10] Le Houerou, H.N. Chemical composition and nutritive value of browse in West Africa. In Le Houerou, H.N. (Ed) Browse in Africa ILCA Addis Abba, Ethiopia. 1990: 261-290.

[11] Menninman, M.C., Beate, I.F. and Murphy, G.M. Nutritional evaluation of browse plants in Australia. Journal of Agricultural Research, 1986: 3:305-314.

[12] NRC, National Research Council. Nutrient requirement of sheep. $6^{\text {th }}$ revised edition, National Academy of Science, Washington, DC. 1981. 
[13] Nzamane, N. Possibilities of improvement of natural resources ILCA. FOA Workshop on pasture and fodder improvement for traditional pastoralists. 1984: 15.

[14] Olayiwole, M.B. Cattle industry in Nigeria; problems and prospects. In Livestock and poultry management course (for livestock and veterinary officers) A.E.R.I.S., Ahmadu Bello University, Zaria. K1-K10. 1986.

[15] Paterson, R.L., Karanja, G.M., Nyatu, O., Kariuki, I.W. and Roothaerti, R.L. A review of tree fodder production and utilization within smallholder agroforestry systems. 1998: 41(2): 181-199.

[16] Skoog, D.A. and Donald, M.W. An introduction to analytical chemistry. $12^{\text {th }}$ ed. 1974: 272-273. 